\title{
Accounting and Financial Literacy of Participants in UAE Financial Markets
}

\author{
Mohamed E. Ibrahim \\ Professor at Canadian University of Dubai \\ Esam 0. El Haron \\ Head of Financial Affairs Section \\ Financial Audit Department, Government of Dubai
}

\begin{abstract}
This article seeks to explore the relationship between financial and accounting literacy and individual investors' participation in the UAE financial markets. The article has three objectives. First, it measures the level of financial and accounting literacy among investors in the UAE financial markets. Second, it attempted to expand our understanding of how financial and accounting literacy influences investments decisions. Third, it examines the effects of demographic factors, such as age, gender, education, and nationality on investment decisions. The authors used reliability and regression analysis to explore collected data. The results indicate significant effects of the level of literacy among individual investors on thier participation in the UAE financial markets. However, no significant effects were observed for gender, educational level or nationalty.
\end{abstract}

Keywords: Accounting literacy, financial literacy, financial markets, UAE

\section{INTRODUCTION}

United Arab Emirates (UAE) financial markets are the country's stock exchange markets located in Dubai and Abu Dhabi. Dubai financial market (DFM) was founded in March 2000. Abu Dhabi financial market (AFM) was founded in November 2000. As of the date of writing, there were about 55 companies listed on DFM and about 67 companies listed on AFM. Most of the listed companies are UAE-based companies. Few of these companies have dual listing in the Middle East and North African Countries, known as the MENA region countries. Moreover, foreign companies are mainly from Kuwait, Bahrain, Oman, and Sudan. Accordingly, UAE can be considered as one of the emerging financial markets.

In recent years, some individual and corporate investors have suffered financial losses through their dealings in the financial markets (AL Khaleej times, July 2017). One possible explanation of these losses has been attributed to wrong investment decisions that were based on irrelevant or lack of sound accounting and financial knowledge. This situation highlights the need of having minimum acceptable levels of financial and accounting knowledge for investors to make good investment decisions or the help of professionals or expert advice. In some countries, several laws and regulations have been set to provide important requirements for financial knowledge and expertise even for members of audit committees. For example, in 1999 the New York Stock Exchange (NYSE) added a rule requiring each company to have an audit committee comprising of independent directors who are financially literate and including at least one financial expert (Giacomino, Wall, and Akers, 2009).

This article seeks to explore the relationship between financial and accounting literacy and individual investors' participation in the UAE financial markets. The article has three 
objectives. First, it measures the level of financial and accounting literacy among investors in the UAE financial markets. Second, it attempted to expand our understanding of how financial and accounting literacy influences investments decisions. Third, it examines the effects of demographic factors, such as age, gender, education, and nationality on investment decisions.

Accordingly, the article addresses the following research questions

1. What is the relationship between financial and accounting literacy and the individuals' decision to participate in the financial markets?

2. Does the level of financial and accounting literacy differ by gender?

3. Does the level of financial and accounting literacy differ based on investor's nationality?

4. Do gender and nationality affect the relationship between financial and accounting literacy and investor's decision to participate in a financial market?

Finding answers to the above questions will help us understand some of the aspects of the emerging financial markets in the UAE. In addition, these questions will serve the process of formulating the research hypotheses for statistical testing purposes as showed in section III.

The remainder of the article proceeds as follows. The next section reviews the relevant literature. The third section outlines the research methodology used to conduct the empirical side of the work (design, sample, data collection, statistical models and techniques). The fourth section reports the statistical results and testing of the research hypotheses. The last section discusses the results and outlines their limitations, conclusions, and recommendations.

\section{LITERATURE REVIEW}

This section presents an overview of previous work related to accounting and financial literacy. It starts with the review of the different definitions and measurements and ends up with the effects of financial and accounting literacy on decision making.

\section{Definition of Financial and Accounting Literacy}

In general, there is no agreed upon single or specific definition for accounting and financial literacy. Most of the writers defined accounting and financial literacy in different ways based on the purpose and measurement of accounting and financial literacy. For example, Mandell (2008) defined financial literacy as the most basic economic concepts needed to make sensible saving and decisions. PACFL (2008) defined financial literacy as knowledge of basic economic and financial concepts, as well as the ability to use that knowledge and other financial skills to manage financial resources effectively for a lifetime of financial well-being. Lusardi and Mitchell (2011) defined financial literacy as Knowledge of basic financial concepts, such as the working of interest compounding, the difference between nominal and real values, and the basics of risk diversification. On the other hand, Coates et al. (2007) indicated that the definition of financial literacy includes the concept of accounting literacy. That is financial literacy is the ability to understand the important accounting judgments that management makes, why management makes them, and how management can use those judgments to manipulate financial statements.

\section{Measurement of Financial and Accounting Literacy}

The literature has documented some commonly observed gender gap in stock market participation. To provide a possible explanation for this observation, Almenberg and Dreber (2015) addressed this point and indicated that this phenomenon could be explained by differences in levels of financial literacy. Furthermore, they explored the attitude of risk taking among participants of the stock market in Sweden. 
These writers used a questionnaire that included two sets of questions for measuring financial literacy. The first set of questions measured the basic financial literacy. The second measured advanced financial literacy. The questionnaire also included questions on the willingness of the participants to take risk expressed on a scale from one to ten, where 1 represents "not risk taking at all" and 10 represents "very risk taking". The questionnaire targeted a simple random sample of 1300 adults in the Swedish population between the ages of 18 and 79. Collected data were generated from State Person Address Register (SPAR). The response rate was about forty-five percent, which is a common figure in terms of survey participation in Sweden with no monetary incentives for participation.

A logistic regression analysis was used to explore how financial literacy affects gender gap in stock market participation at the extensive margin and if financial literacy can explain the gender gap in risk taking between males and females.

The results showed that women score was lower in both basic and advanced financial literacy questions. Therefore, women are less likely to participate in stock market. Women also showed less risk taking than men that successfully helped to explain the gender gap in risk taking based on gender.

Chen and Volpe (1998) examined the personal financial literacy of college students and the relationship between student opinions' and decisions based on their level of financial literacy.

The writers used a comprehensive questionnaire that covered the domain of key areas of personal finance, savings and borrowing, insurance, and investments. They asked the participants to answer (52) questions including 36 multiple choice questions on personal finance, eight questions on student opinions' and decisions, and eight questions on demographic data. The questionnaires were distributed to 1800 students from 14 public and private college campuses. The writers received 924 answers with response rate of $51.33 \%$.

The writers analyzed students' financial literacy by subgroups using analysis of variance (ANOVA), and logistic regression models to analyze the differences. The results showed that business majors are more knowledgeable than non-business majors, males are financially literate than females. Accordingly, the study suggested that college students' knowledge on personal finance is inadequate due to the systematic lack of sound personal finance education in college curricula.

Chen and Volpe (2002) examined the gender differences in personal financial knowledge among college students. The authors used a comprehensive questionnaire to determine participants' personal knowledge of important areas of personal finance.

Logistic regression analysis was used to test the gender differences in personal finance by using gender and other demographic factors as independent variable and the financial literacy as the dependent variable.

The results showed that on average women are less knowledgeable about their own personal finance in comparison with men. Furthermore, participants financial literacy was found to be related to education and experience.

Ibrahim and Alqaydi (2013) examined the financial literacy among a sample of individuals residing in UAE and its relation to different forms of personal debts (i.e., bank loans, borrowing from friends/family members, and borrowing through credit cards). 
The authors used a comprehensive questionnaire containing 33 items, of which 28 items measured personal financial literacy and five items measured personal financial attitude. The questionnaire was distributed to a convenience sample of 412 individuals residing in UAE and the response rate was about of $45 \%$.

The results showed that the average level of financial literacy in UAE is $(0.43)$, which is below the reported average in the literature (0.50). Moreover, UAE nationals tend to borrow more from banks than borrowing from friends or family members. Therefore, the writers recommended that the educational levels of UAE should review the financial components of the current educational programs to ensure its effectiveness for increasing the financial awareness and knowledge.

\section{Financial Literacy and investment Decisions}

The basics of both financial and accounting knowledge are important tools to evaluate and analyze all decisions that affect investors behaviors based on their levels of knowledge. Lack of knowledge about basics of financial and accounting topics could explain why some investors are not taking the correct investing decisions when they participate in stock markets. However, financial decisions mostly depend on participants' financial and accounting knowledge. Lack of basic financial and accounting knowledge could be linked to different negative financial behaviors and attitudes such as nonparticipation in stock markets, failure to plan for retirement, and poor borrowing behavior.

De Clercq and Venter (2009) examined the impact that different independent variables have on the level of personal financial literacy knowledge of undergraduate chartered accountants at the school for accounting science at South Africa's largest open distance learning institution. The writers used a comprehensive questionnaire adopted from prior studies with minor changes to selected items to reflect the different financial environment in South Africa. A total of 902 usable responses were received through internet-based-approach. The writers used a test of homogeneity of variance to examine the relation between the financial literacy knowledge and the independent variables used in the questionnaire.

The results indicated that males are more financially literate than females. Furthermore, age was highlighted as an important factor like gender. Younger students were the least financially literate when compared to adults between 30-39 age group. In addition, the learner's level of income has an impact on the financial literacy as higher level of income of a student had a positive effect on the knowledge of personal finance.

Al-Tamimi and Bin Kalli (2009) assessed the financial literacy of a convenient sample of 290 UAE national investors who invest in the local markets. They also examined the relationship between financial literacy and impact of factors that affects the investment decision.

The writers used a modified questionnaire consists of sixty-two questions divided into three parts. The first part covered the demographic and socio-economic information with six questions, The second part presents thirty-seven questions measuring the investment decision of the UAE investors. The last part consisted of questions that dealt with respondents' understanding of investment and finance.

The writers analyzed collected data using a regression analysis model to measure the effect of independent variables and its relationship with financial literacy. Their results indicate that 
financial literacy level and knowledge of respondents is below the needed level. In addition, women shown lower level of financial knowledge than men.

Asong and Gynsare (2012) explored the determinants of university working students' financial literacy in relation to certain demographic characteristics and its impact on taking the investment decisions.

The writers used a comprehensive questionnaire distributed randomly to 250 undergraduate and postgraduate working students from the university of Cape Cost in Ghana. Collected data were analyzed by descriptive statistics, independent sample T-test, and one-way analysis of variance (ANOVA). The results indicated that age, work experience, and mother's education were positively correlated with financial literacy. However, level of education, work location, and father's education were not significantly correlated with financial literacy and investment decisions.

Giacomino, Wall, and Akers (2009) examined the financial literacy among undergraduate accounting and finance students at a private Midwestern university. The writers used an instrument developed and used previously by Coates et al. (2007) as an extension to study the financial literacy of corporate board members and MBA students at the University of Chicago.

The results indicate that undergraduate students are also financially illiterate in comparison to the findings of Coates et al. (2007) which concluded that both groups lack the appropriate level of financial literacy.

Ramasawmy et al. (2013) assessed the level of awareness of financial literacy among students at the University of Mauritius. They aimed at discovering the relationship between financial literacy and some demographic variables such as ager group, gender, and program of study.

The writers used a questionnaire that covers four fundamental important aspects of the study such as the gender of respondents attached to their subjects of study, age group and occupation, possible causes of financial literacy, and possible measures as how to improve financial literacy in Mauritius. The population of the study includes full time, final year management students from the bachelor programs of management, human resources management and marketing management at the University of Mauritius.

The writers analyzed collected data using independent sample t-tests to compare the means of many dependent variables between male and female respondents. In addition, Chi-square test was also used to measure association between categorical variables, and other factors such as age group, gender and program of study, and financial literacy level. Their results indicate that overall, most students at the University of Mauritius have a medium level of knowledge and skills in financial literacy and in saving and borrowings. Moreover, no significant difference between male and female respondents was observed for the level of financial literacy. While Significant difference was observed between male and female for the ability to read, analyze, manage, and communicate, it was found that age, gender, language, race and income level do not have any impact on the level of financial literacy.

Xiao et.al. (2014) examined the association between gaining financial literacy early and financial behaviors later among college students at a major state university in the UAE. Financial literacy was measured by both subjective and objective knowledge. Financial behaviors were categorized in terms of the risk associated with borrowing and paying behaviors. 
Data were collected from a panel of students at two points in time with three years difference. At the earlier date, financial knowledge was measured in terms of objective and subjective items and financial behaviors of the same group of students were measured in terms of their risky borrowing and paying behaviors.

The results indicated that the association between earlier knowledge and later financial behaviors differed by the specific type of financial knowledge (objective versus subjective) with stronger effects of subjective financial knowledge. These results were at the composite and individual measures of risky borrowing and payment behaviors. In addition, the writers found consistent differences for each of the control variables (cumulative grade point average and gender).

Gaudecker (2015) pointed out that the economic theory predicts that investors will hold their risky assets in the form of diversified portfolio. However, the literature points out to some cases of under diversified portfolio, Accordingly, he investigated the case of under diversified portfolio to estimate quantitatively meaningful statistics to in relation to some key variables such as financial literacy, professional counseling, or private contacts for advice.

The writer used data that were collected from respondents to the Dutch household survey and found that nearly all households that scored high on financial literacy or relied on professionals or private contacts for advice achieved reasonable investment outcomes compared to those groups of households with median financial literacy. In addition, those who trust their own decision capabilities lose an expected 50 base points on average.

Krische (2015) studied the impact of individual investors financial literacy on assessment of incentive-based conflict of interest. Based on fundamentals of different aspects of accounting, prior research suggests that less sophisticated investors may be at disadvantage in understanding the influence of incentives.

Using a large sample of graduate students and replication of two financial accounting experiments, the results show that investors with higher financial literacy are more sensitive to incentives and more likely to incorporate their personal reactions and understanding into their judgments. On the other hand, those investors with lower financial literacy or noninvestors are less likely to incorporate incentives in their judgments when compared with those of higher financial literacy. The writer also attempted to expand our understanding of the role of financial literacy in investment decisions by including individual cognitive characteristics such as information processing.

Sulaiman (2016) linked the literature on financial knowledge and capabilities with performance of small and medium size firms. Data were collected from small and medium size firms operating in Australia.

The writer used factor analysis and multiple regression analysis to test the hypothesized relationships. The analyses yielded some interesting results. It was found that a general business education degree (e.g., Master of Business Administration) and the firm's learning orientation are the most influential drivers of firm performance. A generalized understanding of the business and the ability to learn, adapt, and pivot are what matters the most. Interestingly enough, it was also found that the experience of the Chief Executive Officer (CEO) and the formal relations with the teams do not significantly influence firms' performance. 


\section{RESEARCH METHODOLOGY}

This section describes the research methodology used to complete the study. It starts with the questionnaire design followed by the sampling and data collection. The section then describes the research variables and their measurement and ends up with the statistical models and techniques to be used.

\section{Questionnaire Design}

The Literature on financial and accounting literacy we reviewed in section II indicates the use of different questionnaires. Some writers have used exam-type questions (e.g. multiple-choice questions or agreement/disagreement with statements), while others have used Likert-type scale items. The questionnaire used in this research consists of forty-three questions of which 24 questions measure the level of financial literacy and 19 questions measure accounting literacy. The financial literacy items were adopted from Ibrahim and Alqaidi (2013) questionnaire. The accounting literacy items were adopted from different sources with the main one being Trombetta (2016).

The questionnaire draft was pilot-tested by three academicians and three professional financial analysts. Based on received feedback, the authors made some changes to the wording of some of the questions. A copy of the final questionnaire is included in the appendix.

\section{Sampling and Data collection}

The population from which a convenient sample was selected consists of participants of the two financial markets in the UAE (Dubai and Abu Dhabi FM). Questionnaires were distributed in different ways. Some questionnaires were handed out to participants in person when they visited the trading floor at the financial market. Other questionnaires were emailed to persons who were identified as investors by the second author as they are his colleagues at work, friends, and classmates. Some other questionnaires were handed out to some participants of a College conference on financial markets and trade that was held in Dubai in early April 2017. The total number of distributed questionnaires reached 548.

\section{Research variables and measurements}

This research has five independent variables. They are participant's gender, nationality, Educational level, financial literacy, and accounting literacy. Participation in one of the two main Financial Markets represents the dependent variable. A brief description of each of these variables and their measurement is as follows.

Participation a Financial Market: This variable represents participants identified behavior through buying, holding or selling financial instruments in the market. Participation in the Financial Market was measured through the answer to question six on the questionnaire.

Financial Literacy: This variable refers to a person's knowledge in the financial area. This variable was measured by the average percentage of the correct answers to the 24 financial questions covering five dimensions: investment, inflation and interest rate, protection, saving and borrowing, and pension.

The items related to the investment dimension was represented by questions $9,10,37 \mathrm{~A}, 37 \mathrm{H}$, $37 \mathrm{~J}, 37 \mathrm{~K}$, and $37 \mathrm{M}$. The inflation and interest rate dimension was represented by three items on questionnaire represented by questions 15,16 , and 17 . The protection dimension was represented by six-items on the questionnaire represented by questions 37B, 37C, 37D,37F, 37I, and 37L.The saving and borrowing dimension was measured by six items on the questionnaire represented by questions $8,11,12,13,14$, and $37 \mathrm{~N}$.The pension dimension was represented by items $37 \mathrm{E}$ and $37 \mathrm{G}$. 
Accounting Literacy: This variable refers to a person's knowledge in the financial accounting area. This variable was measured by the average percentage of correct answers to 19 items on the questionnaire covering three dimensions: basic financial statements, disclosure, and internal controls. The items related to the basic financial statements were eleven and represented by questions 18, 19, 20,21, 22, 23, 24, 25, 26, 27, and 28. The disclosure dimension has five items and were represented by the items on questions, 29,30,31,32, and 33 . The internal control dimension has three items and was represented by questions 34,35 , and 36.

\section{Research Hypotheses}

Based on the research questions posed in the first section of the article, the authors formulated the following five null hypotheses:

$\mathbf{H}_{\mathbf{0 1}}$ : There is no significant relationship between the gender of a participant and his participation in the financial markets.

$\mathbf{H}_{\mathbf{0 2}}$ : There is no significant relationship between a participant's nationality and his participation in the financial markets.

$\mathbf{H}_{\mathbf{0}}$ : There is no significant relationship between the level of the participant's education and his participation in the financial markets.

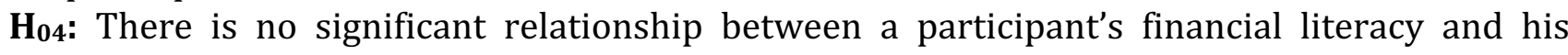
participation in the financial markets.

$\mathbf{H}_{05}$ : There is no significant relationship between a participant's accounting literacy and his participation in the financial markets.

\section{Statistical Techniques and Research model}

The authors used descriptive statistics; reliability analysis and a regression analysis model to analyze collected data. Reliability analysis (Cronbach's alpha) was used to measure the strength of the internal consistency of the items representing financial and accounting literacy. The authors used also the reliability analysis results to eliminate the items that did not load on the assumed factors.

Regression techniques were used to identify the effect of each independent variable on participation in the financial market. The regression model was specified using the selected variables, presented earlier. The regression model took the following form:

Where,

$$
Y_{A}=\alpha+B_{1} X_{1}+B_{2} X_{2}+B_{3} X_{3}+B_{4} X_{4}+B_{5} X_{5}+\varepsilon .
$$

$\mathrm{Y}_{\mathrm{A}}=$ indicates the participants' participation in the Financial Markets.

$\mathrm{X}_{1}=$ represents the gender classification of the participant.

$\mathrm{X}_{2}=$ represents the nationality classification of the participant.

$\mathrm{X}_{3}=$ represents respondents' educational level of the participant.

$\mathrm{X}_{4}=$ represents respondents' average score of financial literacy.

$\mathrm{X}_{5}=$ represents respondents' average score of accounting literacy.

$\varepsilon=$ represents the randomly distributed error.

The results of data analyses (descriptive statistics, reliability analysis, and the regression analyses) are reported in the section below.

\section{DATA ANALYSES AND FINDINGS}

This section reports the results of the statistical analysis obtained from analyzing collected data. We first present the sample responses followed by the reliability analysis results 
(Cronbach's alpha results). The regression results and testing the research hypotheses ends this section.

\section{Sample Responses}

The authors distributed 548 questionnaires to a convenient sample of individuals and received back 356 responses of which 9 responses were excluded due to incomplete data. The remaining 347 usable questionnaires represent a response rate of about $63 \%$.

Table (1) provides information about the sample distribution of demographical variables that include gender, age, nationality, educational level, and marital status.

With respect to the gender, about $65 \%$ were males (35\% were females). For the age categories, about $90.5 \%$ of the respondents were in the age category of 20 years to less than 50 years. The remaining $9.5 \%$ of respondents were in the age category of 50 years and above.

Table (1) shows that $53 \%$ of the respondents were classified as UAE nationals and the other $47 \%$ non-UAE Nationals. Moreover, $5.2 \%$ of the respondents had an educational level below Bachelor's degree, $60.2 \%$ hold bachelors' degree. About $9.5 \%$ were classified as holders of post graduate diplomas. The remaining 25.1\% had advanced graduate degree (Master/Doctorate).

Table (1)

Sample Distribution of Demographical Variables

\begin{tabular}{|l|l|c|c|}
\hline Variable & \multicolumn{1}{|c|}{ Category } & Frequency & Percentage \\
\hline Gender & Male & 226 & 65.1 \\
& Female & 121 & 34.9 \\
\hline Age & 20 to less than 50 & 314 & 90.5 \\
& 50 and above & 033 & 9.5 \\
\hline Nationality & UAE Nationals & 184 & 53.0 \\
& Non-Nationals & 163 & 47.0 \\
\hline Level of Education & Below Bachelor's degree & 18 & 05.2 \\
& Bachelor's degree & 209 & 60,2 \\
& Post Graduate Diploma & 33 & 09.5 \\
& Advanced Graduate degree & 87 & 25.1 \\
& (Master/Doctorate) & & \\
\hline Marital Status & Single & 259 & 25.7 \\
& Married & 8 & 72.0 \\
& Other & & 02,3 \\
\hline
\end{tabular}

Table (1) also shows that about $72 \%$ of the respondents were married and about $26 \%$ of the respondents were singles.

\section{Data Reduction and Reliability Analysis}

The authors used test-retest Reliability analysis to identify the items that did not load on the assumed factors. The extraction method of the principal component was used in the analysis. The analysis reduced financial literacy items to 14 items covering 4 dimensions (i.e., investment, inflation and interest rate, protection, and pension). The accounting items were similarly reduced to 15 items covering 3 main dimensions (i.e., basic financial statements, disclosure, and internal controls).

The authors also used reliability analysis for the multi-item measures of financial and accounting literacy using Cronbach's alpha coefficient. The analysis measures the strength of 
the internal consistency among the items representing the measures. Table (2) reports the obtained alpha coefficients

Table (2)

Alpha Coefficients of Financial and Accounting Literacy

\begin{tabular}{||l|c|c||}
\hline \multicolumn{1}{|c|}{ Variable } & Number of Items & Cronbach's Alpha \\
\hline Financial Literacy & 14 & 0.687 \\
\hline Accounting Literacy & 15 & 0.735 \\
\hline Financial \& Accounting Literacy & 29 & 0.786 \\
\hline
\end{tabular}

Table (2) shows that the Cronbach's alpha reliability coefficients are higher than the minimally acceptable level of .65 to .70 (DeVellis, 2016). Therefore, collected data can be accepted and analyzed using the regression analysis models as planned.

\section{Regression Analyses}

Table (3) shows the regression analysis results for effects of demographic variables and the total score of financial literacy and accounting literacy on participation in the UAE financial markets.

Table (3)

Regression Results for Financial and Accounting Literacy

\begin{tabular}{l|r|r|r}
\hline \multicolumn{1}{c|}{ Variable } & \multicolumn{1}{c}{ Beta } & \multicolumn{1}{c}{ t-value } & \multicolumn{2}{c}{ Level of Significance } \\
\hline Gender & 0.193 & 1.792 & .076 \\
\hline Nationality & 0.150 & 1.451 & .150 \\
\hline Education & 0.085 & 0.918 & .361 \\
\hline Accounting Literacy & 0.428 & 2.166 & .033 \\
\hline Financial Literacy & 0.565 & 1.957 & .053 \\
\hline
\end{tabular}

$\mathrm{R}^{2}=0.175$, Adjusted $\mathrm{R}^{2}=0.134, \mathrm{~F}=4.257, \mathrm{P}=<0.001, \mathrm{n}=347$

The results indicate that the model is significant $(F=4,257, \mathrm{P} .<0.001)$ which means that the model specification is acceptable. Table (3) also shows that accounting literacy is statistically significant at $\mathrm{p} \leq 0.033$ and financial literacy had a mild effect at $\mathrm{p} \leq 0.053$.

Table (3) also shows that nationality and education were not statistically significant ( $\mathrm{p} \geq$ 0.150 ). However, gender shows mild effect at $\mathrm{p} \leq 0.076$.

Table (4) shows the obtained results for the components of the accounting literacy. The table shows that the regression model is statistically significant $(F=26,778, P$. $<0.001)$, which means that the model specification is acceptable. It seems that segmentation of the dimensions of the accounting literacy weakened the components effect. This means that each component of the accounting literacy by itself does not contribute significantly to participation in the financial markets. In fact, the effect of disclosure and internal controls are statistically insignificant ( $p \geq 0.223$ ). Only basic financial statements show mild effect ( $p \leq 0.067$ ). However, with the segmentation of accounting literacy, nationality becomes statistically significant at $\mathrm{p} \leq 0.036$ and gender also becomes statistically significant at $p \leq 0,051$. 
Table (4)

Regression Results for Accounting Literacy

\begin{tabular}{l|r|r|rc}
\hline Variable & Beta & t-value & Level of Significance & \\
\hline Gender & .157 & 1.971 & .051 \\
\hline Nationality & .191 & 2.122 & .036 \\
\hline Financial Statement & .299 & 1.849 & .067 \\
\hline Disclosure & .145 & 1.225 & .223 \\
\hline Internal Controls & .128 & 1.098 & .275 \\
\hline
\end{tabular}

$\mathrm{R}^{2}=0.570$, Adjusted $\mathrm{R}^{2}=0.549 \mathrm{~F}=26.778, \mathrm{P}=<0.001, \mathrm{n}=347$

\section{Testing the Research Hypotheses}

The previous section formulated five hypotheses that were stated in the null form. The first stated that there is no significant relationship between the gender of participants and participation in financial markets. The regression results reported in Table (3) indicate that there is no significant relationship between gender and participation in financial markets. Therefore, the results fail to reject the first null hypothesis.

The second research hypothesis stated that there is no significant relationship between nationality of the individual and his participation in financial markets. The regression results reported in Table (4) indicate that there is no significant relationship between nationality of the individual and participation in financial markets. Accordingly, the results fail to reject the second null hypothesis.

The third research hypothesis stated that there is no significant relationship between the level of education of the individual and his participation in financial markets. The regression results reported in Table (4) indicate that there is no significant relationship between the level of education and participation in financial markets. Thus, the results fail to reject the third null hypothesis.

The fourth research hypothesis stated that there is no significant relationship between financial literacy and participation in financial markets. The regression results reported in Table (4) indicate that there is no significant relationship between financial literacy and participation in financial markets. Therefore, the results fail to reject the fourth null hypothesis.

The last research hypothesis stated no significant relationship between the accounting literacy and participation in Financial Markets. The regression results reported in Tables (3) indicate that there is a significant relationship between accounting literacy and participation in financial arkets. Thus, the results reject the fifth null hypothesis.

\section{DISCUSSION, CONCLUSIONS, AND RECOMMENDATIONS}

This section discusses the results and the conclusions. It also articulates some of limitations and recommendations.

Although the results indicate lack of statistical significant regarding the effects of demographic variables, in participation in the financial markets, the authors view this result in a positive way. It points toward the non-discriminatory attitude based on gender, nationality, or educational levels. As an open modern society, every individual is having the freedom to participate in the financial markets as he sees fit. However, nationality and gender becomes 
significant when accounting literacy was segmented into its three components. This indicates that males had more accounting knowledge than females. Also expatriates have more accounting knowledge than UAE nationals.

The summation of the components of accounting literacy seems to have a suppression effect as the collective effect becomes statistically significant. Also the financial literacy is statistically significant in terms of its effect on participation in the financial markets. This result is in-line with the general trend in most of developed countries.

The reported results are subject to some limitations. The authors list here four of these limitations. First, the length of the questionnaire may have affected the response of some participants, although the response rate is high and acceptable in social science research. Second, the results may not be generalizable to the whole population of UAE. However, the large size of the sample may mitigate the effect of this limitation. third, most of the reviewed literature have dealt with financial markets outside the UAE which did not allow for comparisons of the reported results. Last, the authors used a linear ordinary least-square regression while others have used logit regression. Although we did not find any anomalies in the data screening phase to suggest the need for a non-linear regression model, it is possible that using other form may yield different results.

\section{CONCLUSIONS}

The reported results lead the authors to the following conclusions:

1. The result that financial and accounting literacy affects investors' participation in UAE financial markets leads the authors to conclude that Individuals participating in the financial markets take their participation decisions with some level of tolerable risk which can expose them to some losses. One possible implication for such a behavior is that financial attitude of investors will take some time before it can be improved.

2. The result that gender has no effect on participation in financial markets leads the authors to conclude that the UAE authorities handling the affaires of the financial markets have very transparency policies with investors that are not based on gender. Furthermore, it is a good sign for the civility of the financial markets and financial institutions. One possible implication for this conclusion is that financial markets of UAE have the potential to positively grow sooner than later.

3. The result that educational level has no effect on participation in financial markets leads the authors to conclude that the educational and financial institutions do not provide high quality of financial education and awareness. One possible implication of this situation is the weak performance of financial markets as we have seen in the past few years.

4. The result that nationality has no effect on the participation in Dubai financial Market. This means that the financial institutions treat all residents and investors equally. One of the implications for such a conclusion is the increase of numbers of participants' in the UAE financial markets.

\section{RECOMMENDATIONS}

The authors provide the following three recommendations.

1- Although financial and accounting literacy of investors in UAE is at good level $(48 \%)$ compared with the international level (about 50\%), the authors suggest that the UAE authorities of financial markets and professional organizations (e.g., Accountants and Auditors' Association) organize public forums and awareness programs to demonstrate 
the importance of financial and accounting knowledge as well as participation in financial markets.

2- Researchers should replicate this study and include a larger sample size if possible with an emphasis on participation in other financial markets in the Gulf Countries. The results of such studies may help increase the level of integration among these countries and the eventual planned common market.

3- Basic finance and accounting knowledge should be incorporated in the curriculum of every university major. This task would be part of the role of the Ministry of Higher Education and Scientific Research of UAE (MOHESR). Providing this knowledge to the new generation would greatly improve their chances in actively participating in the financial markets.

\section{References}

DeVellis, R.F. (2016), Scale development Theory and Applications, SAGE Publication Inc.

Al-Khaleej Times (July 2017), “Financial market news,” Al-Khaleej Time incorporation, UAE.

Almenberg, J., Derber, A. (2015), “Gender, stock market participation and financial literacy," Economics Letters, 137,140 .

Al-Tamimi, H. and Bin Kalli, A. (2009), "Financial literacy and investment decisions of UAE investors," The Journal of Risk Finance, 10 (5), 500.

Asong, A., and Gyesare, M. (2012), “Determinants of university working -students' financial Literacy at the university of Cape Cost, Ghana," Journal of Business and Management, 7 (8), 126.

De Clercq, V. (2009), "Factors influencing a prospective chartered accountants level of financial literacy," Meditari Accountancy Research, 17 (2), 47.

Chen, H. and Volpe, R. (1998), "An analysis of personal financial literacy among college students," Financial Services Review, 7 (1), 107.

Chen, H. and Volpe, R. (2002), "Gender differences in personal financial literacy among college students," Financial Services Review, 11 (3), 289.

Coates, D., Marais, M., Weil, R. (2007)," Audit committee financial literacy: A work in progress," Journal of Accounting, Auditing, and Finance, 22 (2), 175.

Giacomino, D., Wall, J., and Akers, M. (2009), "Revisiting financial (accounting) literacy): A comparison of audit committee members and business students," American Journal of Business Education, 2 (3), p. 31

Gaudecker, M. Von (2015), How does household portfolio diversification vary with financial literacy and financial advice," Journal of Finance, 70 (2), 489.

Ibrahim, M. E. and Alqaydi, F. (2013), "Financial literacy, personal financial attitude, and forms of personal debt among residents of the UAE," International Journal of Economics and Finance, 5 (7), 126.

Krische, S. (2015), “The impact of individuals' financial literacy on assessment of conflict of interest," Working Paper, American University, Washington, D.C.

Lusardi, A., and Mitchell, O. (2011), "Financial literacy around the world: An overview," Journal of Pension Economics and Finance, 10 (3), 497.

Mandell, L. (2008), "Financial literacy of high school students," As in Xiao, J. (editor), Handbook of Consumer Finance, Springer.

President Advisory Council on Financial Literacy (PACFL, 2008), the 2008 report, Washington, D.C.

Ramasawmy, D., Thapermall, S., Dowlut, S., and Raman, M. (2013), "A study of the level of awareness of financial literacy among management undergraduates," Proceedings of the $3^{\text {rd }}$ Asian Pacific Business Research Conference, 25-26 February, Kuala Lumpur, Malaysia, ISBN: 978-1-922069-19-1.

Sulaiman, N. (2016), "The impact of financial knowledge and capabilities on small firm performance in Australia," $P h D$. Thesis, RMIT University, Australia.

Trombetta, M. (2016)," Accounting and finance literacy and self-employment: An exploratory study," Working Paper, IE Business School, IE University, Spain. 
Xiao, J., Syahn, S., Serido, J., and Shim, S. (2014), "Earlier financial literacy and later financial behavior of college students," International Journal of Consumer Studies, 38 (6), 593.

\section{APPENDIX \\ The Research Questionnaire}

This questionnaire is used to collect information to complete a research project dealing with financial markets. The questionnaire is anonymous where no individual person will be identified or connected with a set of information or research findings.

Your cooperation in completing this questionnaire is greatly appreciated.

Please respond to each of the following items:

1. Your gender

__ Male

2. Your age

Female

3. Your nationality between 21 to less than 50 50 and above

4. Your highest educational level: Non-UAE national Below bachelor's degree Bachelor's degree Postgraduate Diploma Advanced graduate degree (Master/Doctorate)

5. Your marital status Single Married

6. Do you currently own shares of one or more companies?

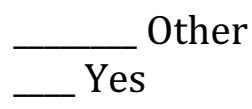
Other No

7. Please insert a check mark $(\sqrt{ })$ in the appropriate column to indicate your ranking of the importance of each of the following items using the following five-point scale:

\begin{tabular}{|c|c|c|c|c|c|c|c|c|}
\hline $\begin{array}{c}\text { NOT IMPORTANT AT } \\
\text { ALL }\end{array}$ & $\begin{array}{l}\text { SOMEWHAT } \\
\text { IMPORTANT }\end{array}$ & NEUTRAL & $\begin{array}{c}\text { VERY } \\
\text { IMPORTANT }\end{array}$ & & \multicolumn{4}{|c|}{$\begin{array}{l}\text { EXTREMELY } \\
\text { IMPORTANT }\end{array}$} \\
\hline 1 & 2 & 3 & 4 & \multicolumn{5}{|c|}{5} \\
\hline \multicolumn{4}{|c|}{ Item } & 1 & 2 & 3 & 4 & 5 \\
\hline \multicolumn{9}{|c|}{ Maintaining adequate financial records } \\
\hline \multicolumn{9}{|c|}{ Spending less than income regularly } \\
\hline \multicolumn{9}{|c|}{ Maintaining adequate insurance coverage } \\
\hline \multicolumn{9}{|c|}{ Maintaining diversified investment portfolio regularly } \\
\hline \multicolumn{4}{|c|}{ Avoid borrowing to balance personal budget } & & & & & \\
\hline \multicolumn{4}{|c|}{ I have high confidence in my investment decisions } & & & & & \\
\hline
\end{tabular}

8. Alia works for the Government of Dubai. She has saved AED 80,000 for her university education. Her plan is to start university next year and needs all the money she saved. Which of the following is the safest place of her university money?

Locked in her closet at home

Stocks.

Corporate bonds.

A bank savings account

9. Which of the following types of investment would best protect the purchasing power of a family's in the event of a sudden increase in inflation?

A 10-year bond issued by a corporation.

A certificate of deposit at a bank.

A twenty-five year corporate bond.

A house financed with a fixed -rate mortgage. 
10. Many people put aside money to take care of unexpected expenses. If Jamal and his wife Eva have money put aside for emergencies, in which of the following forms would it be of LEAST benefit to them if they needed it right away?

Invested in a down payment on a house.

Stocks.

Saving account.

Checking account.

11. Dalia just found a job with a take-home pay of AED 8,000 per month. She must pay AED 4,000 for rent and AED 1,500 for groceries each month. She also spends AED 250 per month on transportation. If she budgets AED350 each month for clothing and AED 600 for everything else, how long will it take her to accumulate savings of AED 2,400?

One month

Two months

Three months

Four months

12. Ahmed and Ali are of the same age. At age 25, Ahmed began saving AED 20,000 a year while Ali saved nothing. At age 50, Ali realized that he needed money for retirement and started saving AED 40,000 per year while Ahmed kept saving his AED 20,000. Now they are both 75 years old. Who has the most money in his retirement account?

They would each have the same amount because they contributed the same.

Ali, because he saved more each year.

Ahmed, because he has saved each year

Ahmed, because his money has grown for a longer time at compound interest.

13. Nagy and Bilal work together in the finance department of the same company and earn the same pay. Bilal spends his free time taking work-related classes to improve his computer skills; while Nagy spends his free time socializing with friends and working out a fitness center. After five years, what is likely to be true?

Nagy will make more because he is more social.

Nagy will make more because Bilal is likely to be laid off.

Bilal will make more money because he is more valuable to his company.

Nagy and Bilal will continue to make the same money.

14. Sara and Mustafa had a baby. They received money as baby gifts and want to put it away for the baby's education. Which of the following tends to have the highest growth over 18 years?

Stocks.

A government savings bond.

A savings account.

Checking account.

15. Suppose you had AED 1,000 in a savings account and the interest rate was $2 \%$ per year. After five years, how much would you have in the account if you left the money to grow?

More than AED 1,020.

Exactly AED 1020.

Less than AED 1,020.

Do not know

16. Imagine that the interest rate on your savings account was $2 \%$ per year and inflation was $4 \%$ per year. After one year, how much goods and services would you be able to buy with the money in this account? 


\section{More than today. \\ Exactly the same. \\ Less than today. \\ Do not know.}

17. A refrigerator has a list price of AED 4,200. You can buy it for AED 3,600 cash now or through three equal monthly payments. Assume the annual interest rate on bank loans is $8 \%$. Which payment option do you think is preferable?

Three equal payments.

Cash.

There is no difference between the two options.

Do not know.

18. The balance sheet

Is a financial snapshot, taken at a point in time, of the assets the company owns and the claims assets.

Records the flow of financial resources over time.

Reports the operating results of a company for a period.

Is prepared by the auditors.

Both a and d are correct

19. Shareholders' equity (owners' equity, stockholders' equity, net worth, or equity)

Is a source of reserve assets consisting of undistributed income?

Is the amount of cash contributed by the shareholders?

Includes shareholder contributions and undistributed income.

Is dependent on the company's stock price fluctuations.

Both $\mathrm{c}$ and $\mathrm{d}$ are correct.

20. Basic earnings per share (EPS) is calculated by

Dividing net income by the number of common shares Outstanding at the end of the reporting period.

Dividing net income by the weighted average number of preferred and common stock outstanding during the reporting period.

Dividing income before taxes by the number of common shares outstanding at the end of the reporting period.

Dividing net income attributable to common shareholders by the weighted average number of common shares outstanding during the reporting period.

Varies from company to company.

21. Which of the following balance sheet items generally do not require management to make significant Judgments and/or estimates?

Inventory at lower of cost or market

Net receivables

Cash

Accrued liabilities

Both a and c are correct

22. A company should only consolidate its financial statements with a company in which it owns 50 percent or more equity shares.

True 
False

23. Which of the following is NOT true of related-party transactions?

Only transactions requiring material cash payments between related parties need to be disclosed.

A company cannot indicate in its financial statements that related-party transactions were consummated under terms that were similar to those that could have been achieved in an arms' length transaction unless this representation can be substantiated. The substance of related-party transactions is more important than their form. All the above are true of related-party transactions.

24. A sale can be recorded when delivery has NOT occurred if several criteria are met, including

Risk of ownership has passed to the buyer.

There is a sales commitment.

There is a fixed delivery date.

All of the above are required.

Both a and $\mathrm{c}$ are required

25. Management is required to record any adjustments that the auditors propose.

True

False

26. An amount is always immaterial to the financial statements if it is less than

10 percent of income before taxes.

10 percent of shareholders equity.

2 percent of net assets.

None of the above

27. Financial ratios are tools that allow you to understand the economic activity of a company without having to understand accounting.

True

False

28. The quick ratio, a tool used to assess liquidity, is defined as:

(Current assets - Inventory)

Current liabilities

True

False

29. Which of the following is NOT considered a financial disclosure for a public company?

Management Discussion \& Analysis (MD\&A)

Earnings announcements.

The company's financial statements.

All of the above are forms of financial disclosure.

Both a and $\mathrm{c}$ are financial disclosures.

30. Which of the following financial information is Covered by the independent auditors' report?

Earnings announcements 
Pro forma earnings releases

The footnotes to the financial statements

MD\&A

All the above.

31. Which of the following items is NOT expected to be addressed in Management Discussion \& Analysis (MD\&A)?

The most critical accounting policies used to prepare the financial statements.

Liquidity and capital resources.

Any item that helps investors assesses the company's current condition and prospects.

All the above are expected to be addressed in MD\&A.

32. Which of the following is NOT a required disclosure?

A significant loan agreement

Interest rate

Significant covenants

Name of the lender

Schedule of maturity

All the above are required to be disclosed.

33. Non-cash charges, such as asset impairments,

Should be ignored during most analyses, as they do not have an impact on the cash

flows of the company.

Should be ignored during most analyses only if they are nonrecurring charges and are not indicative of the ongoing operations of the company.

Can be put "below the line" on the income statement to signal to investors that the item should be removed before analysis.

Are the results of situations that may have diminished the economic value of the company?

None of the above.

34. Internal controls are designed to provide reasonable assurance over the
A. Effectiveness and efficiency of operations.
B. Reliability of financial reporting and information.
C. Compliance with applicable laws and regulations.
D. All of the above.

Both $\mathrm{b}$ and $\mathrm{c}$.

35. An effective system of internal control will always prevent and detect fraud.

True

False

36. Who is responsible for the design and effectiveness of the company's internal controls?

Management

Internal audit

External audit

The audit committee

All of the above 
37. Please insert a check mark $(\sqrt{ })$ in the appropriate column to indicate whether you agree or disagree with each of the following statements:

\begin{tabular}{|c|c|c|c|c|}
\hline & Statement & Agree & Disagree & Do not know \\
\hline A & $\begin{array}{l}\text { Buying a single company stock usually provides a } \\
\text { safer return than a group of stocks. }\end{array}$ & & & \\
\hline B & $\begin{array}{l}\text { Health Insurance policies usually contain maximum } \\
\text { annual amounts to be paid to medical doctors and } \\
\text { hospitals }\end{array}$ & & & \\
\hline $\mathrm{C}$ & $\begin{array}{l}\text { A homeowner's insurance policy will often pay the } \\
\text { medical expenses of a guest who is injured on your } \\
\text { property. }\end{array}$ & & & \\
\hline D & $\begin{array}{l}\text { It's a good idea to buy less insurance for an old car } \\
\text { than for a new car }\end{array}$ & & & \\
\hline E & $\begin{array}{l}\text { If your pension scheme invested AED } 100,000 \text { in } \\
\text { shares of a company, it would be possible to have the } \\
\text { shares valued at more or less than AED 100,000 after } \\
\text { one year }\end{array}$ & & & \\
\hline $\mathrm{F}$ & $\begin{array}{l}\text { Life insurance has more value for a couple with young } \\
\text { children than for a couple whose children are grown. }\end{array}$ & & & \\
\hline G & $\begin{array}{l}\text { To earn the highest expected long term growth, a } \\
\text { pension scheme should invest in Treasury bills }\end{array}$ & & & \\
\hline $\mathrm{H}$ & $\begin{array}{l}\text { In periods of economic growth, financial leverage does } \\
\text { not work well for the company }\end{array}$ & & & \\
\hline I & $\begin{array}{l}\text { The main purpose of insurance is to reduce the } \\
\text { financial risk faced by a consumer }\end{array}$ & & & \\
\hline$J$ & $\begin{array}{l}\text { Holding diversified stock portfolio reduces financial } \\
\text { risk inherent in stock market }\end{array}$ & & & \\
\hline $\mathrm{K}$ & $\begin{array}{l}\text { A return on capital is the relationship between income } \\
\text { and total assets }\end{array}$ & & & \\
\hline $\mathrm{L}$ & $\begin{array}{l}\text { A larger deductible on an insurance policy is always a } \\
\text { bad deal for the consumer because the insurer pays } \\
\text { less of the consumer's losses. }\end{array}$ & & & \\
\hline M & $\begin{array}{l}\text { A high-risk high return investment strategy is suitable } \\
\text { for an elderly retired couple living on fixed income }\end{array}$ & & & \\
\hline $\mathrm{N}$ & $\begin{array}{l}\text { The rate of interest on your credit card is usually } \\
\text { higher than what you can earn on a certificate of } \\
\text { deposit }\end{array}$ & & & \\
\hline
\end{tabular}

Thank you for your cooperation

If you would like to receive a copy of the results, please provide your:

Name:

Mailing address or (e-mail): 